\title{
METHANE PRODUCTION FROM STILLAGE
}

\author{
Vilis Dubrovskis, Imants Plume \\ Latvia University of Agriculture \\ vilisd@inbox.lv, imants.plume@inbox.lv
}

\begin{abstract}
By-products from production of alcohol distilling dregs (stillage) contain much organic matter, therefore could be useful for the production of biogas. The purpose of the study is assessment of the methane volume obtainable from stillage in the anaerobic fermentation process. Investigation was provided in 16 bioreactors operated in batch mode at $38^{\circ} \mathrm{C}$. Stillage was filled into 14 bioreactors and only inoculum was filled into two bioreactors for control. The yield of biogas was $0.616 \mathrm{l} \cdot \mathrm{g}^{-1}$ DOM and methane $0.360 \mathrm{l} \cdot \mathrm{g}^{-1}$ DOM after 37 days of anaerobic digestion. The investigated average methane content in biogas from stillage was $58.5 \%$. The study demonstrates that stillage is a good raw material for the production of methane.
\end{abstract}

Key words: methane; stillage, anaerobic digestion.

\section{Introduction}

The alcoholic beverage plants are characterized by relatively large quantities of liquid organic byproducts. Recycling or further use of such by-products is not fully solved in Latvia. The biogas production from distilling dregs residue can be considered as the most suitable technology for alternative energy production due to large amount of organic solids. However, balanced composition of active substances in substrate should be provided to ensure activity of the bacteria for successful biomethane production.

Biodegviela Ltd. is one of three distilleries in Latvia located in Kalsnava. The factory has been expanding production by building the fuel alcohol plant. Production of biogas is provided both from distilling stillage residue $450 \mathrm{t} \cdot \mathrm{d}^{-1}$ and cattle manure $60 \mathrm{t} \cdot \mathrm{d}^{-1}$, and total cogeneration electrical capacity is $2 \mathrm{MW}$ el. Heat produced is used for technological purposes.

The distilling stillage residue utilization for production of feed additives is ongoing in Iecava alchocol plant, and the by-products utilization is provided only partially in Jaunpagasts alcoholic beverages plant. Suitability of distilling stillage residue for biogas production can be judged from raw material analysis (Table 1) [3].

Table 1

Analysis of distillery stillage from Kalsnava alcohol factory

\begin{tabular}{|c|c|}
\hline Parameter & Amount \\
\hline $\mathrm{pH}$ & $\sim 3$ \\
\hline Humidity $\mathrm{W} \%$ & 92 \\
\hline Dry matter, DM $\mathrm{g} \cdot \mathrm{l}^{-1}$ & 90 \\
\hline Ashes, $\mathrm{A}, \mathrm{mg} \cdot \mathrm{l}^{-1}$ & 3.3 at $850^{\circ} \mathrm{C}$ (Dry mass of the residue) \\
\hline Phosphorus, $\mathrm{P}, \%$ by weight & 0.7 \\
\hline Nitrogen, $\mathrm{N}, \%$ by weight & 4.57 \\
\hline Carbon $(\mathrm{C}, \%$ by weight & 42.13 \\
\hline Hydrogen, $\mathrm{H}, \%$ by weight & 6.05 \\
\hline
\end{tabular}

Distilling stillage is a residual product of the ethanol production process and it is good raw biomass for production of biogas. The potential of biogas from stillage was investigated by many researchers in different countries [1-11].

In recent years, many of industrial distilleries, particularly those using cellulose containing raw biomass, have started the usage of distillery stillage also for biogas production in order to improve energy and economic effectiveness. Three main types of raw materials - wheat, triticale and cellulose containing the raw materials - were used for ethanol production worldwide. The wheat and triticale grains are used almost exclusively in distilleries in Latvia, even though the price on grain is relatively high, but there are lower transport expenses on locally produced grain suitable for high quality ethanol production.

Researchers at the Swedish University of Agricultural Sciences (SLU) have estimated the biogas potential from wheat stillage using five laboratory bioreactors during 640 days at temperature 
$38^{\circ} \mathrm{C}$. Stability problems arise after 120 days of the anaerobic fermentation process, while stillage was used as the only biomass medium in the digester. The anaerobic digestion process was stabilized after cattle manure was added into bioreactors, so providing the organic load (OLR) of $2.8 \mathrm{~g}^{-1}$ vs. The investigated methane yield per unit of volatile solids (VS) was $310 \mathrm{ml} \cdot \mathrm{g}^{-1} \mathrm{vs}$ for pulp $(85 \%)$ and manure mixture (15\%), and the hydraulic retention time (HRT) was 45 days [10].

Researchers at the University of Florida investigated stillage produced from grain and raw materials with a high cellulose content treatment in the anaerobic digestion process. Investigations showed that quite similar biogas quantity is obtainable from raw materials in mesophilic or in thermophilic treatment mode, but the thermophilic process can be provided almost twice as fast, so the digester can to work with double organic load (OLR) [8] in thermophilic treatment.

The theoretical biogas potential investigated at the Swedish University of Boras was $0.473 \mathrm{~m}^{3} \cdot \mathrm{kg}^{-1}$ vs or $0.407 \mathrm{~m}^{3} \cdot \mathrm{kg}^{-1}$ vs from wheat stillage or cellulose stillage respectively. The average methane yield was $0.288 \mathrm{~m}^{3} \cdot \mathrm{kg}^{-1}$ vs or $0.218 \mathrm{~m}^{3} \cdot \mathrm{kg}^{-1}$ vs from wheat or cellulose stillage respectively [9].

The highest potential of $691-788 \mathrm{ml} \cdot \mathrm{g}^{-1} \mathrm{vs}$ biogas and $401-458 \mathrm{ml} \cdot \mathrm{g}^{-1} \mathrm{vs}$ methane was obtained from maize stillage. The rate of organic matter decomposition was 76-94 \% [14].

The German researchers also collected information [6], but with less data on stillage anaerobic fermentation.

The outcome of biogas from stillage is not investigated in Latvia before. The hydrogen sulphide content usually increases in stillage substrate during anaerobic fermentation, so additional measures should be provided to reduce this harmful substance.

The purpose of the study is evaluation the biogas and methane production from stillage in the anaerobic fermentation process.

\section{Materials and methods}

The raw biomass material (stillage) samples were analysed to clear up the general elements before fermentation. The data were used for calculation of organic loading rates.

16 bioreactors were filled with substrate and placed in the heated container-thermostat Memmert, and gas released from each bioreactor was collected into separate flexible storage bags located outside the thermostat. The widely applied methods were used for preparation of raw biomass substrate, investigation of the fermentation process and analysing of the results [12;13].

Dry organic matter (DOM) content was determined by investigation of raw weight, dry weight and ashes weight of substrate components and mixtures before and after the anaerobic fermentation process using a moisture-balance measuring unit (model MOC-120H) at $105{ }^{\circ} \mathrm{C}$ temperature and the oven (model Nabertherm) at $550^{\circ} \mathrm{C}$. All mixtures were prepared, carefully mixed and all bioreactors were placed into the container-thermostat at the same time before starting of the anaerobic digestion process. Gases volumes were measured using the flow meter (Ritter drum-type gas meter). The composition of gases, e.g., oxygen, carbon dioxide, methane, and hydrogen sulphide, was measured using the gas analyser (model GA 2000). The substrates $\mathrm{pH}$ values were measured before and after finishing of the anaerobic digestion using the $\mathrm{pH}$ meter (model PP-50). Total weight of substrates before and after the anaerobic fermentation process was measured with the scales (model KFB 16KO2).

2 bioreactors were filled with $500.0 \pm 0.2 \mathrm{~g}$ inoculums only (for control) and 14 bioreactors (all having volume of $0.75 \mathrm{l})$ were filled with mixtures of inoculums $(500 \mathrm{~g})$ and added stillage $(20 \pm 0.005 \mathrm{~g})$. Almost completely fermented cattle manure from 1201 bioreactor working in continuous mode was used as the inoculums. Batch mode anaerobic digestion process was provided at thermostat temperature $38 \pm 0.5^{\circ} \mathrm{C}$. Biogas released from each bioreactor was collected into a gas bag both for the gas volume and content measurements at regular time intervals. The anaerobic fermentation process was provided until biogas release ceases within 37 days.

\section{Results and discussion}

Amount of raw material was prepared, mixed and preciously distributed between reactors (R2R15), and accuracy of substrate dose in every reactor equals to measurement accuracy of the scales 
used. The results of investigation of raw biomass substrates, including inoculums and stillage components, are shown in Table 2.

Table 2

Results of analyses of raw material samples before anaerobic digestion

\begin{tabular}{|c|c|c|c|c|c|c|c|c|}
\hline $\begin{array}{c}\text { Bio- } \\
\text { reactor }\end{array}$ & $\begin{array}{c}\text { Raw } \\
\text { material }\end{array}$ & pH & $\begin{array}{c}\text { TS, } \\
\text { \% }\end{array}$ & $\begin{array}{c}\text { TS, } \\
\mathbf{g}\end{array}$ & $\begin{array}{c}\text { ASH, } \\
\mathbf{\%}\end{array}$ & $\begin{array}{c}\text { DOM } \\
\mathbf{\%}\end{array}$ & $\begin{array}{c}\text { DOM, } \\
\mathbf{g}\end{array}$ & $\begin{array}{c}\text { Weight, } \\
\mathbf{g}\end{array}$ \\
\hline $\begin{array}{c}\text { R1; } \\
\text { R16 }\end{array}$ & IN & 7.44 & 0.36 & $1.800 \pm 0.005$ & 49.25 & 50.75 & $0.914 \pm 0.005$ & $500 \pm 0.2$ \\
\hline & S & 4.29 & 11.18 & $2.236 \pm 0.005$ & 6.18 & 93.82 & $2.098 \pm 0.005$ & $20 \pm 0.005$ \\
\hline R2-R15 & IN+S & 7.28 & 0.78 & $4.036 \pm 0.005$ & 26.37 & 74.63 & $3.012 \pm 0.005$ & $520 \pm 0.21$ \\
\hline
\end{tabular}

Abbreviations: IN - inoculum; $S$ - stillage; ASH - ashes; TS - total solids; DOM - dry organic matter (on raw substrate basis); R1-R16 - bioreactors.

As it can be seen from the raw materials analyses in Table 1 stillage contains higher dry matter $(11.18 \%)$ and organic dry matter (6-8 \%) content compared to that from other distilleries.

The results of analysis of finished digestate from every bioreactor after the anaerobic fermentation process are shown in Table 3.

Table 3

Results of analyses of finished digestate

\begin{tabular}{|c|c|c|c|c|c|c|c|c|}
\hline Reactor & Substrate & $\mathbf{p H}$ & $\begin{array}{c}\text { TS } \\
\mathbf{\%}\end{array}$ & $\begin{array}{c}\text { TS } \\
\mathbf{g}\end{array}$ & $\begin{array}{c}\text { ASH } \\
\mathbf{\%}\end{array}$ & $\begin{array}{c}\text { DOM } \\
\mathbf{\%}\end{array}$ & $\begin{array}{c}\text { DOM, } \\
\mathbf{g}\end{array}$ & $\begin{array}{c}\text { Weight, } \\
\mathbf{g}\end{array}$ \\
\hline R1 & $500 \mathrm{~g}$ IN & 7.58 & 0.35 & 1.743 & 49.10 & 50.90 & 0.887 & 498.2 \\
\hline R16 & $500 \mathrm{~g}$ IN & 7.60 & 0.35 & 1.743 & 49.94 & 50.06 & 0.872 & 498.0 \\
\hline R2 & $500 \mathrm{~g} \mathrm{IN+20gS}$ & 7.48 & 0.52 & 2.612 & 76.84 & 23.16 & 0.605 & 502.4 \\
\hline R3 & $500 \mathrm{~g}$ IN+20gS & 7.6 & 0.34 & 1.725 & 36.51 & 63.49 & 1.095 & 507.4 \\
\hline R4 & $500 \mathrm{~g}$ IN+20gS & 7.52 & 0.38 & 1.930 & 42.18 & 57.82 & 1.116 & 508.0 \\
\hline R5 & $500 \mathrm{~g}$ IN+20gS & 7.48 & 0.28 & 1.420 & 70.96 & 29.04 & 0.585 & 507.0 \\
\hline R6 & $500 \mathrm{~g}$ IN+20gS & 7.42 & 0.38 & 1.931 & 43.11 & 56.89 & 1.099 & 508.2 \\
\hline R7 & $500 \mathrm{~g}$ IN+20gS & 7.46 & 0.37 & 1.880 & 40.23 & 59.77 & 1.123 & 508.0 \\
\hline R8 & $500 \mathrm{~g}$ IN+20gS & 7.51 & 0.39 & 1.980 & 39.34 & 60.66 & 1.201 & 507.8 \\
\hline R9 & $500 \mathrm{~g}$ IN+20gS & 7.50 & 0.38 & 1.929 & 38.25 & 61.75 & 1.191 & 507.6 \\
\hline R10 & $500 \mathrm{~g}$ IN+20gS & 7.55 & 0.40 & 2.031 & 39.51 & 60.49 & 1.229 & 507.8 \\
\hline R11 & $500 \mathrm{~g}$ IN+20gS & 7.54 & 0.39 & 1.980 & 39.58 & 60.42 & 1.196 & 507.7 \\
\hline R12 & $500 \mathrm{~g}$ IN+20gS & 7.55 & 0.39 & 1.981 & 41.88 & 58.12 & 1.151 & 508.0 \\
\hline R13 & $500 \mathrm{~g}$ IN+20gS & 7.44 & 0.38 & 1.930 & 41.51 & 58.49 & 1.129 & 507.8 \\
\hline R14 & $500 \mathrm{~g}$ IN+20gS & 7.49 & 0.39 & 1.979 & 40.38 & 59.62 & 1.180 & 507.6 \\
\hline R15 & $500 \mathrm{~g}$ IN+20gS & 7.52 & 0.40 & 2.032 & 42.18 & 57.82 & 1.175 & 508.0 \\
\hline R2-R15 & Average & 7.50 & 0.385 & 1.953 & 45.16 & 54.84 & 1.076 & 507.4 \\
\hline
\end{tabular}

The production of biogas and methane from stillage and from control reactors is presented in Table 4.

The inoculums continue to degrade slightly in average by $0.034 \mathrm{~g} \mathrm{DOM}$ or by $3.77 \%$ in the control bioreactors R1 and R16, see Table 3. The remaining average total dry organic matter of substrates with stillage and inoculums (R2-R15) was $1.076 \mathrm{~g}$, and the calculated total biodegradation rate was $64.28 \%$. The calculated remaining average dry organic matter of the stillage component in finished substrate (R2-R15) was $(0.196 \mathrm{~g})$, and average biodegradation rate of stillage was $90.66 \%$. Even in theoretically the worst case, if the inoculums can be degraded by $100 \%$, stillage should still degrade by $0.197 \mathrm{~g}$ or by $9.37 \%$ to match the experimental results. In fact, the calculated biodegradation rate of inoculum was negligible, and the volume of biogas in the control reactors R1 and R16 with inoculums was so small that it was not possible to distinguish any gases volume using 
the above mentioned measurement techniques, see Table 4. It confirms that stillage has lot of easy degradable substances facilitating the anaerobic fermentation process.

Table 4

Production of biogas and methane

\begin{tabular}{|c|c|c|c|c|c|}
\hline $\begin{array}{c}\text { Bioreactor/Raw } \\
\text { material }\end{array}$ & $\begin{array}{c}\text { Biogas, } \\
\text { l }\end{array}$ & $\begin{array}{l}\text { Biogas, } \\
l \cdot g^{-1} \text { DOM }\end{array}$ & $\begin{array}{c}\text { Methane, } \\
\text { aver. \% }\end{array}$ & $\begin{array}{c}\text { Methane, } \\
\text { l }\end{array}$ & $\begin{array}{c}\text { Methane, } \\
l \cdot g^{-1}\end{array}$ \\
\hline R1 500g IN & 0 & 0 & 0 & 0 & 0 \\
\hline R16 500g IN & 0 & 0 & 0 & 0 & 0 \\
\hline R2 500g IN+20gS & 1.2 & 0.572 & 61.3 & 0.736 & 0.351 \\
\hline R3 500g IN+20gS & 1.4 & 0.667 & 56.11 & 0.786 & 0.374 \\
\hline $\mathrm{R} 4500 \mathrm{~g} \mathrm{IN}+20 \mathrm{gS}$ & 1.5 & 0.715 & 57.42 & 0.861 & 0.411 \\
\hline R5 500g IN+20gS & 1.2 & 0.572 & 58.83 & 0.706 & 0.337 \\
\hline R6 500g IN+20gS & 1.3 & 0.620 & 58.42 & 0.759 & 0.362 \\
\hline R7 500g IN+20gS & 1.2 & 0.572 & 59.14 & 0.710 & 0.338 \\
\hline R8 500g IN+20gS & 1.2 & 0.572 & 58.18 & 0.698 & 0.333 \\
\hline R9 500g IN+20gS & 1.3 & 0.620 & 57.83 & 0.751 & 0.358 \\
\hline R10 500g IN+20gS & 1.3 & 0.620 & 58.28 & 0.758 & 0.361 \\
\hline R11 500g IN+20gS & 1.2 & 0.572 & 59.23 & 0.711 & 0.339 \\
\hline R12 500g IN+20gS & 1.4 & 0.667 & 56.83 & 0.796 & 0.379 \\
\hline R13 500g IN+20gS & 1.4 & 0.667 & 57.13 & 0.800 & 0.381 \\
\hline R14 500g IN+20gS & 1.2 & 0.572 & 60.12 & 0.721 & 0.344 \\
\hline R15 500g IN+20gS & 1.3 & 0.620 & 60.18 & 0.782 & 0.373 \\
\hline $\begin{array}{c}\text { Average, } 500 \mathrm{~g} \\
\mathrm{IN}+20 \mathrm{gS}\end{array}$ & $1.3 \pm 0.15$ & $0.616 \pm 0.072$ & $58.5 \pm 2.3$ & $0.755 \pm 0.082$ & $0.360 \pm 0.039$ \\
\hline
\end{tabular}

Note: $l \cdot g^{-1}$ Dom - litres per $1 \mathrm{~g}$ dry organic matter added (added fresh biomass into inoculums).

The average methane content in biogas from stillage is shown in Fig. 1.

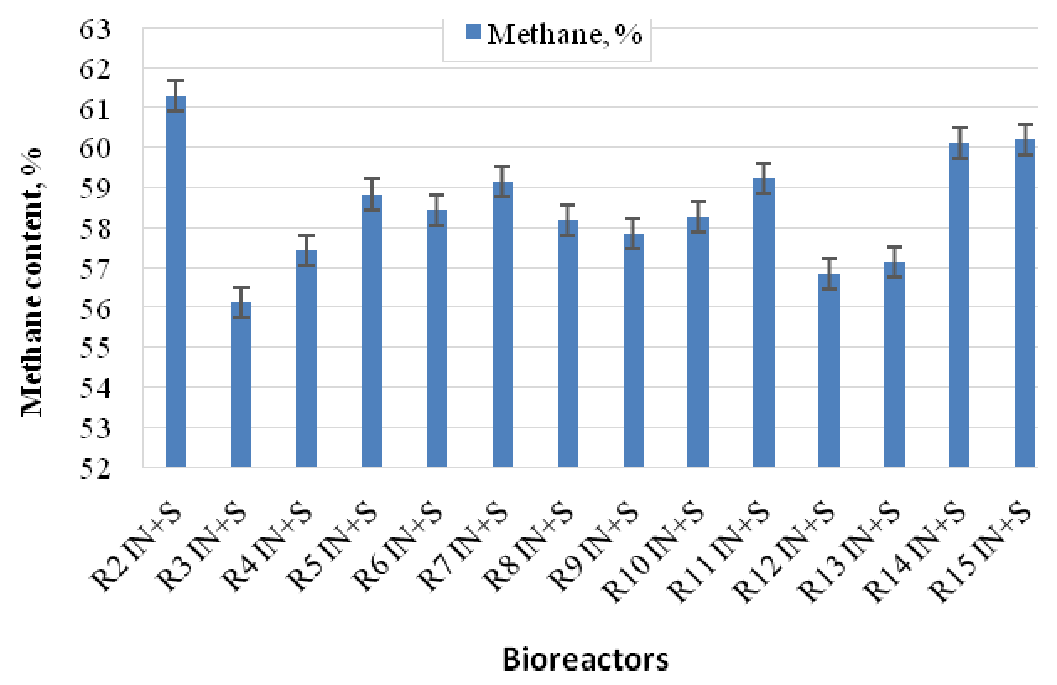

Fig. 1. Average methane content in biogas produced from stillage

The relatively high methane content in biogas from stillage can be explained by the fact that stillage contains a lot of raw sugars. There was a high hydrogen sulphide content observed in biogas, even 2-3 times higher compared to the permissible level $(150 \mathrm{ppm})$, especially at the beginning of the anaerobic fermentation process. To prevent damage to the equipment, while working with stillage, it is required to reduce the formation of hydrogen sulphide or to provide the treatment of biogas before its utilisation in cogeneration engines.

The specific average biogas and methane production volumes $\left(1 \cdot \mathrm{g}^{-1}\right.$ DOM $)$ calculated for bioreactors with added stillage biomass are shown in Fig. 2. The specific biogas and methane yields (Table 4 and 
Fig. 2) are representing the average data calculated for the whole period of the stillage anaerobic digestion process.

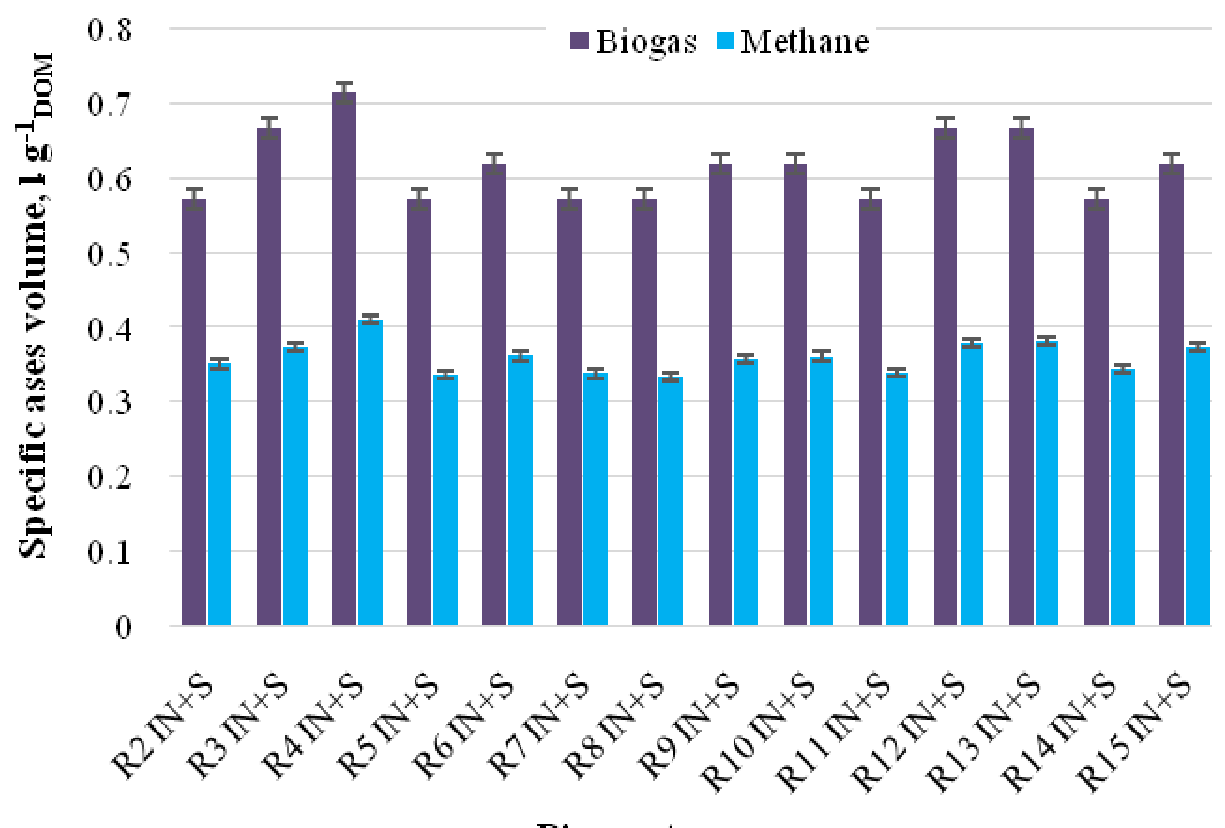

Bioreactors

Fig. 2. Average specific biogas and methane yields from stillage

The good results obtained are similar to the literature data reported from other studies $[8 ; 10 ; 13 ;]$. It could be explained by the fact that the stillage biomass chemical composition is consisting of substances easily degradable by micro-organisms (having much sugars and juice easily accessible by bacteria).

\section{Conclusions}

1. The investigated average specific biogas yield was $0.616 \pm 0.072 \mathrm{l} \cdot \mathrm{g}^{-1}{ }_{\text {DOM }}$ of raw stillage organic matter.

2. Relatively high average specific methane yield was obtained from stillage (mean value $0.360 \pm 0.039 \mathrm{l} \cdot \mathrm{g}^{-1}$ DOM download).

3. The investigated relatively high methane content in biogas of $58.5 \%$ confirms that stillage from ethanol plants is a good resource for biomethane production.

4. Relatively high content of hydrogen sulphide in biogas was observed during the stillage anaerobic fermentation process, therefore biogas purifying should be provided before its usage in cogeneration engines.

\section{Acknowledgements}

This investigation was supported by the Latvian National Research Programme LATENERGI.

\section{References}

1. Dubrovskis V., Adamovičs A. Bioenergétikas horizonti (Horizons of bioenergetics), Jelgava: Latvia University of Agriculture, 2012. 352 p. (In Latvian).

2. Drosg B. Comparing centralized and decentralized anaerobic digestion of stillage from a large scale bioethanol plant to animal feed production. Water Science and Technology, vol. 58(7), 2008, pp. 1483-1489.

3. Eskicioglu C., Kennedy K.J., Marin J. et al. Anaerobic digestion of whole stillage from dry-grind corn ethanol plant under mesophilic and thermophilic conditions. Bioresource Technology, vol. 102, 2011, pp. 1079-1086.

4. Kaparaju P., Serrano M., Angeldaki I. Optimization of biogas production from wheat straw stillage in UASB reactor. Applied Energy, vol. 87, 2010, pp. 3779-3783. 
5. Kim Y., Mosier N.S., Hendrickson R. et al. Composition of corn dry-grind ethanol by-products: DDGS, wet cake and thin stillage. Bioresource Technology, vol. 99, 2008, pp. 5165-5176.

6. Schaefer S.H., Sung S. Retooling the ethanol industry: Thermophilic anaerobic digestion of thin stillage for methane production and pollution prevention. Water Environment Research, vol. 80(2), 2008, pp. 101-108.

7. Schaefer S.H. Re-tooling the ethanol industry: Thermophilic anaerobic digestion of thin stillage for methane production. Master's thesis - Civil Engineering Department, Iowa State University, Ames Iowa, 2006, 86 p.

8. Wilkie A.C., Riedesel K.J., Owens J.M. Stillage characterization and anaerobic treatment of ethanol stillage from conventional and cellulosic feedstocks. Biomass and Bioenergy, vol. (19), 2000, pp. 63-102.

9. Awosolu M. Anaerobic digestion of ethanol distillery waste-stillage for biogas production Msc. thesis, Hogskolan Boras, 2008, 62 p.

10. Westerholm M, Hansson M, Schürer A. Improved biogas production from whole stillage by codigestion with cattle manure. Bioresources Technol., vol. 114, 2012, pp. 314-319.

11. Stover E.L., Gomathinayagam G., Gonzalez R. Use of methane from anaerobic treatment of stillage for fuel alcohol production. Proceedings of the 39th Industrial Waste Conference, Purdue University, West Lafayette, Indiana, Boston, vol. 1984. pp. 57-63.

12. Becker C. et al. Faustzahlen Biogas (Calculations of biogas), Publisher Kuratorium für Technik und Bauwesen in der Landwirtschaft, 2007, Darmstadt, 181 p. (In German).

13. Kaltschmitt M. Methodenhandbuch (Methods Manual), 2010, Leipzig, 93 p. (In German).

14. Ghorbani M. Effect of inoculum/substrate ratio on mesophilic anaerobic digestion of bioethanol plant whole stillage in batch mode Process Biochemistry, 2011, vol. 46(8), 2011, pp. 1682-1687. 